\title{
Villas, Villagers and Tortoises in Greece
}

In the summer of 1980 four members of the University of London Natural History Society went to Lake Alyki in Macedonia to study a population of tortoises Testudo hermanni. Such studies are urgently needed because very little is known about the ecology of Mediterranean tortoises, which are declining seriously, due mainly to habitat loss and collecting for the pet trade. The expedition chose Alyki after an expedition by the same society in 1979 had reported an exceptionally rich wildlife there including a large tortoise population. A new holiday village nearby did not appear to threaten the main wildlife areas, and a commercial salt works only operated at the north end of the lake from which access to the heath was not easy. However, unknown to the four members, the 1980 expedition had walked into an explosive situation. The following account is quoted from their report.

The 1980 expedition arrived at Alyki exactly one year after the previous visit. The road from Pydna to Kitros had been metalled and the old fish taverna by the harbour had closed down. Everything else appeared the same, the holiday village was still only half-built, and, most important, the tortoise heaths remained undisturbed. On July 11 Adrian Hailey (AH) and David Stubbs (DS) made a tour of inspection. Their first source of concern was an apparent lack of certain bird species, in particular slender-billed gulls. However, gull-billed terns were still common and Mediterranean gulls were still abundant, although the colony had shifted. In the first hour they counted 34 Testudo hermanni along the path between the sluices and lighthouse, a good number by any standard. A new dyke was being constructed across the southern saltmarsh, but this was well away from the important bird colonies. More curious was the new road being built across the extensive rough grazing area, which, the workmen said, was for access to the beach; they were about a mile from their target.

On the evening of July 12 , in conversation with people from Kitros and Katerini, it was learned for the first time that there were plans to build holiday homes on the heaths. Three days later AH and DS were approached by two men and a woman from Kitros. The woman, who lived in England, interpreted for the men, who were obviously important members of the village committee.

In the winter of 1979/80 they said the village had applied for planning permission to build holiday homes on the Alyki heaths. This had been refused on the grounds that the area was a valuable wildlife refuge. The evidence cited was from an unspecified report on the birdlife of Alyki. The villagers remembered 'the four Englishmen' from the previous summer, and the reappearance of two more this year suggested that the expedition was in some way involved with that report. One of the Kitros men had visited the ministry and seen the report, but could not understand it, presumably because it was in English. Probably it was in fact an extract from the 1979 expedition account, orwarded to the Greek authorities. 
On being assured that our expedition was not knowingly involved in these events and that no future reports would be submitted to the Greek authorities, the Kitros men gave $\mathrm{AH}$ and DS permission to continue camping on the heaths.

The land in question, the coastal strip between the lake and sea, belongs to the village of Kitros and until now has been unused apart from occasional cattle grazing. The villagers were particularly annoyed at the planning refusal for two main reasons. First, there had been no official objections to previous applications from German companies wishing to build factories along this coast. (Why these were not built is not clear.) Second, the salt works, which are government-owned, were undergoing a major expansion, with new salt pans being built at the southern end of the lake complex. The villagers realise, quite correctly, that when the new works are completed and the salinity builds up, all the birdlife will disappear. The ornithological importance of the area is mostly due to the lake, and, although the heaths are also rich in birdlife, the original report, which caused all the controversy, was mainly referring to the wetland birds.

\section{The Strategy}

The government's hypocritical stance led the villagers to consider cashing in themselves on any potential development. As the second expedition was concentrating on the heaths, the villagers were worried that the authorities might be encouraged to conserve tortoises as well. The new road was to provide access to the building site and the villagers had collectively paid the construction costs. Without planning permission they would have a good, expensive road going nowhere! So to ensure that their second application was successful they adopted a scorched earth policy. By deliberately destroying the wildlife value of the heaths they hoped to defy the authorities to find a valid excuse for refusing the plans.

\section{Destruction}

On July 17, while exploring the southern heaths, $\mathrm{AH}$ noted that a bull-dozer had started work levelling the vegetation. After two days a strip of about $500 \mathrm{~m}$ $x 100 \mathrm{~m}$ had been cleared. On July 19 a major fire was started deliberately, along the entire length of the southern heaths. Fortunately the wind direction prevented the fire spreading further than the lighthouse, but it was clear that there would be little time left to complete the tortoise study.

The predictable disaster happened on July 24 when the main study area was set alight. The wind was blowing off the sea, so the coastal heath vegetation was

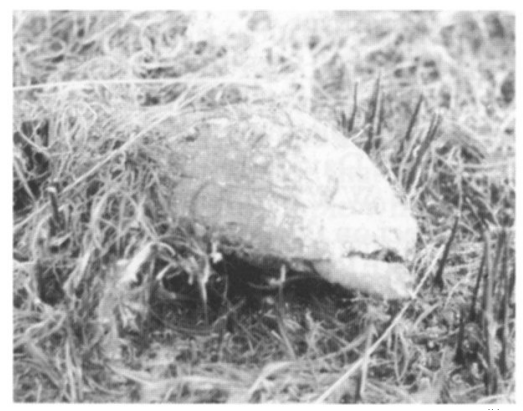


undamaged and two sampling areas also escaped. This fire was closely monitored by the expedition members; photographs were taken and many dead tortoises found. This was followed up by the bulldozer and a tractor and rotavator to finish off the destruction. Their progress was alarmingly rapid and large areas of habitat were soon laid to waste. A brief respite occurred when the workmen took a few days off, allowing further vital work to be carried out on the remaining tortoises. On August 2 another fire destroyed the grid sampling area and the coastal heath was the only remaining intact area. On this occasion one of the workmen was actually observed setting fire to the vegetation, using petrol-soaked rags.

By the end of the first week in August the blitz was over. Most of the former heaths had been totally levelled and there were several large mounds where scrub and small trees had been bulldozed together. The effect of the rotavator was horrific. There was no chance of any tortoise surviving, and many critically maimed and chopped specimens had to be put out of their extreme pain by expedition members. It was a most distressing scene.

Little change was noted during the brief return visit to Alyki in late August, and this was confirmed on September 5 by Mr J. Walmsley who was inspecting the site.

\section{Consequences}

Three weeks of senseless destruction reduced a complex and fascinating ecosystem to a desert. The loss of another valuable wildlife area on the Mediterranean coast has removed a breeding site for many species of rare birds and several thousand tortoises. Scientifically the tragedy lies in the loss of a site which held an extremely large tortoise population, so suitable for studying. The lack of ecological knowledge on Mediterranean tortoises makes rational conservation planning impossible, and the work on that population would have provided vital basic data.

According to the Expedition Report* the fires killed up to 40 per cent of the tortoises in the affected areas, and the ploughing and levelling killed up to 10,000 over an area of 150 ha. Before the destruction the expedition had estimated the tortoise population in their 75 ha study area at about 5000 , with an average density of 55 per ha. In the best habitat - dry heathland with scattered scrub - densities may have exceeded 150 per ha. They also found that the population was roughly equally divided into adult males, adult females and juveniles. The maximum age was about 50 years. Detailed measurements were made of nearly 800 tortoises, and the report discusses several facets of tortoise ecology.

The expedition received a grant from the Oryx 100\% Fund. POSTSCRIPT

In a recent communication from the Hellenic Society for the Protection of Nature it is reported that the ministry for Co-ordination and Planning are still refusing planning permission, despite continued pressure from the people of Kitros. David Stubbs, in conjunction with Dr Ian Swingland, Chairman of the IUCN/WWF Tortoise Specialist Group, has started on a three-year research project on the population ecology of T.hermanni in southern France, supported by a NERC grant.

*Expedition to Greece 1980, by David Stubbs, Adrian Hailey, Wendy Tyler and Liz Pulford, University of London Natural History Society, ULU, Malet St, London WC1E 7HY, £3 + 50p p\&p. 